$\overline{\text { Original }}$

\title{
Binding Sites on Tau Proteins as Components for Antimicrobial Peptides
}

\author{
NAHOKO KOBAYASHI,, JUNICHI MASUDA ${ }^{1,2}$, JUN KUDOH ${ }^{2,3}$, \\ NOBUYOSHI SHIMIZU, AND TETSUHIKO YOSHIDA ${ }^{1,2 *}$ \\ 'Institute for Advanced Sciences, Toagosei Co., Ltd., \\ Ookubo, Tsukuba, Ibaraki 300-2611, Japan, \\ ${ }^{2}$ Advanced Research Center for Genome Super Power, Keio University, \\ Ookubo, Tsukuba, Ibaraki 300-2611, Japan, \\ ${ }^{3}$ Department of Molecular Biology, Keio University School of Medicine, \\ Shinanomachi, Shinjuku-ku, Tokyo 160-8582, Japan
}

Received February 7, 2008/Accepted February 23, 2008

To design new antimicrobial peptides, we have focused on various proteins which are not essential for self-defense but carry important responsibilities for biosystems. Previously, we reported that highly efficient antimicrobial properties or antiviral properties are inherent in the nuclear translocation signals and binding sites on laminin receptors. Here we introduce microtubule binding sites on tau proteins as new components for antimicrobial peptides. Strong antimicrobial activities against Staphylococcus aureus and Escherichia coli were found in tandem sequences of the binding sites on tau proteins. Moreover, the binding sites obtained significantly strong antimicrobial activities against bacteria and fungi when combined with a nuclear localization signal (NLS) and/or a peptide derived from a binding site of a laminin receptor. The antimicrobial activities of some of the tau-derived peptides were not affected by salt, cations, or serum that simulate the natural environment present in blood. Tau proteins so far have only been known as one of the microtubule-associated proteins (MAPs) which are especially abundant in the central nervous system within the brain. Our finding demonstrates that the binding sites on tau proteins possess high potential for becoming components in antimicrobial peptides. Designs based on binding sites of various proteins could become a useful method in peptide antibiotic research.

Key words : Tau/Binding site/Antimicrobial peptide/Nuclear localization signal/Laminin receptor protein.

\section{INTRODUCTION}

Many pathogenic microorganisms exist in nature and come in contact with our skin and trachea, but we still manage to remain healthy and avoid infection most of the time. This is due to our high quality immunity system, which is how human beings can maintain such an antibody response. Recently, one simple system of that innate immunity which plays an important

${ }^{*}$ Corresponding author. Tel $:+81-29-865-2605$, Fax $:+81$ 29-865-2612. role in the protection against pathogenic infections has been identified, and that is the secretion of antimicrobial peptides from cells.

Moths which are infected by bacteria produce antimicrobial peptides called cecropins to protect themselves from contracting many serious diseases (Steiner et al., 1981). Bees also produce antimicrobial peptides called melittins for the same reason (Steiner et al., 1981; Casteels et al., 1989). Some peptides had been found in the secretions of amphibian skins more than thirty years ago but were considered a homolog of hormones or 
neurotransmitters. Antimicrobial peptides were commonly found in infected insects and for a long time were thought to have been a unique defense system in invertebrates. Antimicrobial peptides called defensins were reported in human neutrophils in the early 1980s (Selsted et al., 1985). An antimicrobial peptide called magainin was isolated from the secretions of frog (Xenopus laevis) skin (Zasloff, 1987). From the time of these early discoveries, antimicrobial peptides have been recognized as one of the important defense systems in vertebrates as well. An antimicrobial peptide, piscidins, was first isolated from the mast cells (also known as eosinophilic granule cells) of fish (hybrid striped bass; Morone saxatilis $\times$ M. chrysops) in 2001 (Sliphaduang and Noga, 2001). Plectasin, an antimicrobial peptide belonging to the defensins family, is active against bacteria, fungi and viruses and was isolated from a fungus (a saprophytic ascomycete Pseudoplectania nigrella) in 2005 (Mygind et al., 2005). This study identified fungi as a novel source of antimicrobial defensins and also suggested that the defensins of insects, molluscs and fungi arose from a common ancestral gene. More than a hundred different varieties of antimicrobial peptides have been identified in mammalian epithelial tissues over the past two decades. In addition, several hundred varieties of artificial antimicrobial peptides have also been developed based on the identified natural antimicrobial peptides. Antimicrobial peptides are an essential part of the innate immunity that evolved in most living organisms over the course of 2.6 billion years to combat harmful microbes (Zasloff, 2002). At present, there are problems such as the appearance of new pathogenic bacteria and the reemergence of tubercular infection. Antibiotic abuses have contributed to the spread of drug-resistant bacteria and the death toll from antibiotic-resistant bacteria is on the rise. Under such social circumstances, there are expectations that antimicrobial peptides are expected to be the next generation of antibiotics and will become an increasing focus of research all over the world.

Conventional antimicrobial peptides have been researched by isolating natural antimicrobial peptides from organisms and/or developing them based on characteristics of natural antimicrobial peptides such as cationic properties or amphipathic $\alpha$-helices, etc. Unlike these approaches, we have focused on various proteins which are not essential for self-defense but carry important responsibilities for biosystems and previously found that highly efficient antimicrobial properties or antiviral properties are inherent in the nuclear translocation signals and binding sites of laminin receptors across different species
(Kobayashi et al., 2006a, 2006b; Kobayashi and Yoshida, 2006; Kobayashi and Yoshida, 2007). In this study, we will introduce binding sites on tau proteins as new components for antimicrobial peptides. The results demonstrated that tau-derived peptides have the potential to be effective components for antimicrobial peptides.

Tau proteins are one of the microtubule-associated proteins (MAPs) which mediate the regulation of the microtubule function, serve as structural components within cells, and are involved in mitosis, cytokinesis, and vesicular transport in cellular processes. Tau proteins are especially abundant in the central nervous system within the brain and bind microtubules (MTs) to promote tubulin polymerization and stabilize microtubule dynamics (Cleveland et al., 1977; Drechsel et al., 1992). The etiology and pathogenesis of neurodegenerative diseases such as Alzheimer's disease and Pick's disease are known to be disorders resulting in the formation of filamentous deposits of abnormal tau proteins in the brain. Human tau proteins are coded by a single gene consisting of 16 exons on chromosome 17. Six tau isoforms (3R/ON, $3 R / 1 N, 3 R / 2 N, 4 R / 0 N, 4 R / 1 N$, and $4 R / 2 N$ ) are generated by alternative mRNA splicing in exons 2,3 , and 10 and are distinguished by their number of repeat domains. The repeat domains contain either three or four imperfect 18 -amino acid repeats separated by 13- or 14- amino acid long inter-repeats and are localized in the $\mathrm{C}$-terminal half of the protein. The binding to MTs is a complex process mediated in part by a flexible array of weak MT binding sites that are distributed throughout the MT binding domain delineated by these repeats and their inter-repeat sequences. The positive charges of the binding domains are another reason they interact with the surface of negatively charged MTs. Interestingly, 4Rtau isoforms are more efficient at promoting MT assembly and show higher MT binding affinity than 3Rtau isoforms do. This is due to the unique sequence of the inter-repeats between the first and second MT binding repeats in $4 \mathrm{R}$-tau. This inter-repeat sequence has more than twice the binding affinity of any individual MT binding repeat region (Lee et al., 2001; Goedert et al., 1990). A proline-rich region of tau proteins, which are located in a more central location of the protein than the repeat domains are, is also thought to be important for MT interaction (Lee et al., 2001; Goedert et al., 1990).

Investigation was done into whether peptides derived from the binding domains of tau proteins could be effective components for antimicrobial peptides. We particularly focused on the inter-repeat domains and proline-rich regions which are known to possess 
great affinity with MTs. Small parts (6-13 amino acid long peptides) of the inter-repeat domains and the proline-rich regions were synthesized and termed "Tau ${ }^{\text {pepp". }}$ The tandem sequence of $\mathrm{Tau}^{\text {pep }}$ and the peptides consisting of combinations of $\mathrm{Tau}^{\mathrm{pep}}$ and nuclear localization signals (NLS) and/or the laminin receptor peptide (LR) were also synthesized. An antimicrobial assay was performed on these peptides. The experiment results were evaluated based on minimum inhibitory concentrations (MICs) in various kinds of mediums with or without salt, cations, and serum. As a result of the experiments, we found significant antibacterial activity against $S$. aureus in the synthesized peptides. The peptides did not lose this activity even in a medium environment containing salt, cations, and serum. Some of these combinations also improved the antibacterial activity in tau-derived peptides against E. coli. Moreover, this arrangement produced an antifungal function in the tau-derived peptides. These findings demonstrate that the binding sites on tau proteins have a high potential for becoming components in antimicrobial peptides.

\section{MATERIALS AND METHODS}

\section{Peptide synthesis}

The peptides were synthesized by the 9fluorenylmethoxycarbonyl solid phase synthesis method using Rink amide resin on an automated solid-phase peptide synthesizer (APEX 396, Advanced ChemTech, USA). After synthesis, the peptides were cleaved with TFA cocktail reagent (80\% TFA, 6\% 1,2-ethanedithiol, 2\% m-cresol, and $12 \%$ thioanisole) for $3 \mathrm{~h}$, and then precipitated with cold ether and harvested using centrifugation. The cleaved peptides were purified to over $\geq 95 \%$ purity by reverse-phase high performance liquid chromatography on a $\mathrm{C}_{18}$ column.

\section{Bacterial strains and fungal strains}

Staphylococcus aureus IFO12731 as the grampositive bacterium, Escherichia coli IFO3972 as the gram-negative bacterium, and Candida albicans NBRC1594 and Candida albicans TIMM3165 as fungi were used for the MIC evaluation.

\section{Preparation of the bacterial suspension and fun- gal suspension}

Bacterial strains were pre-incubated in a LuriaBertani broth $[1.0 \%(\mathrm{w} / \mathrm{v})$ tryptone, $0.5 \%(\mathrm{w} / \mathrm{v})$ yeast extract, and $0.5 \%(\mathrm{w} / \mathrm{v}) \mathrm{NaCl}, \mathrm{pH} 7.0]$ for 18 hours at $37^{\circ} \mathrm{C}$ until they reached the stationary phase. The cell suspensions were diluted with nutrient broth (NB, Difco), Mueller-Hinton broth (MHB, Difco), cation-adjusted Mueller-Hinton broth (ca. MHB), or cation-adjusted Mueller-Hinton broth with 10\% horse serum (ca. sera. MHB, the horse serum was provided by Nippon Biotest Laboratories) until they were adjusted to approximately $2.0 \times 10^{6} \mathrm{cells} / \mathrm{mL}$. Then, the suspensions were kept in ice and used within the hour. In ca. MHB preparation, $500 \mu \mathrm{L}$ of $10 \mathrm{mg} / \mathrm{mL}$ $\mathrm{CaCl}_{2}$ and $250 \mu \mathrm{L}$ of $10 \mathrm{mg} / \mathrm{mL} \mathrm{MgCl}$ were added to $\mathrm{MHB}$ (total broth volume of $100 \mathrm{~mL}$ ).

Pure cultures of $C$. albicans strains were grown through incubation for 24h in RPMl 1640 broth supplemented with glutamine (Irvine Scientific) [0.165M MOPS buffer and $\left.\mathrm{NaHCO}_{3}, \mathrm{pH} 7.0\right]$ at $35^{\circ} \mathrm{C}$ after being subcultured in a YM agar medium $[0.5 \%(\mathrm{w} / \mathrm{V})$ tryptone, $0.3 \%(\mathrm{~W} / \mathrm{v})$ yeast extract, $0.3 \%(\mathrm{w} / \mathrm{v})$ malt extract, $1.0 \%(\mathrm{w} / \mathrm{v})$ glucose, and $1.5 \%(\mathrm{w} / \mathrm{v})$ agar] at $35^{\circ} \mathrm{C}$ at least twice. Five colonies (diameter of $\geqq$ $1 \mathrm{~mm}$ ) of cultured strains were suspended with $5 \mathrm{~mL}$ of $0.85 \%$ saline and diluted with the RPMI 1640 until they were adjusted to approximately $1 \sim 5 \times 10^{3}$ cells $/ \mathrm{mL}$. Then, the suspensions were used within $15 \mathrm{~min}$ or kept at $4^{\circ} \mathrm{C}$ and used within $2 \mathrm{~h}$.

\section{Antibacterial assay}

The minimum inhibitory concentrations (MICs) of the synthesized peptides were evaluated by following the micro-dilution method. The mediums used were $\mathrm{NB}, \mathrm{MHB}$, ca. MHB, or ca. sera. MHB. The peptidediluted series were prepared with each medium in a 96-well plate, to which the bacterial suspension was added $\left(10^{6} \mathrm{cells} / \mathrm{mL}\right.$ in the total broth volume of 100 $\mu \mathrm{L}$ ) and incubated at $37^{\circ} \mathrm{C}$ for $24 \mathrm{~h}$. The MICs were then determined by visual inspection.

\section{Antifungal assay}

The MICs of the synthesized peptides were evaluated by following the micro-dilution method. The peptide-diluted series were prepared with RPMI $164 \mathrm{p}$ in a 96-well plate, to which the fungal suspension was added $\left(0.5 \sim 2.5 \times 10^{3}\right.$ cells $/ \mathrm{mL}$ in the total broth volume of $200 \mu \mathrm{L}$ ) and incubated at $35^{\circ} \mathrm{C}$ for $24 \mathrm{~h}$. The MICs were then determined by visual inspection.

\section{RESULTS}

\section{Design for antimicrobial peptides}

Proline-rich regions and inter-repeat regions in the carboxy-terminal half of the tau proteins are known as MT binding domains (Bergen et al, 2000; Goode and Feinstein, 1994; Goode et al., 1997; Goode et al., 2000). Peptides derived from $4 R$-tau proline-rich regions and 4R-tau/3R-tau inter-repeat regions were synthesized and termed "Tau"pep" (Table 1). The Tauderived peptides ( $\mathrm{Tau}^{\mathrm{pep}}$ ) are very small, 6-13 amino 
TABLE 1. Sequences of tau-derived peptides.

\begin{tabular}{|c|c|c|}
\hline Peptide & Sequence & Source ${ }^{a}$ \\
\hline $\mathrm{Tau}^{\mathrm{pep}}{ }_{1}$ & VQIVYK & 4R-tau R2-R3 IR aa306-311 ${ }^{b}$, 3R-tau R1-R3 IR \\
\hline $\mathrm{Tau}^{\mathrm{pep}}{ }_{2}$ & VQIINK & 4R-tau R1-R2 aa275-280 \\
\hline $\mathrm{Tau}_{3}^{\mathrm{pep}}$ & KVQIINKKL & 4R-tau R1-R2 IR aa265-273 $3^{d, \theta}$ \\
\hline $\mathrm{Tau}_{4}^{\mathrm{pep}}$ & KKVAVVR & 4R-tau proline-rich region aa215-221 $1^{d}$ \\
\hline $\mathrm{Tau}_{5}^{\mathrm{pep}_{5}}$ & KVQIINKK & 4R-tau R1-R2 IR aa265-272 \\
\hline $\operatorname{Tau}_{6}{ }_{6}$ & KKVAVVRT & 4R-tau proline-rich region aa215-222 ${ }^{d}$ \\
\hline $\mathrm{Tau}_{7}^{\mathrm{pep}}$ & SVQIVYKPV & 4R-tau R2-R3 aa396-304 ${ }^{e}$ \\
\hline $\mathrm{Tau}_{8}^{\mathrm{pep}}$ & KVQIINKKLDLSN & 4R-tau R1-R2 IR aa265-278, \\
\hline
\end{tabular}

acids long. In addition, different combinations of $\mathrm{Tau}^{\text {pep }}$, nuclear localization signal peptides (NLS) and the laminin receptor peptide (LR) were also designed and synthesized. Three kinds of NLS peptides, NLS, (Pax-QNR): LKRKLQR, NLS 2 (NS5A): PPRKKRTVV, $\mathrm{NLS}_{3}$ (The analog sequence of SV40 Large T antigen [PKKKRKV]): RKKKRKV and an LR peptide, LR (lamimin-binding site on human $67-\mathrm{kD}$ laminin receptor): LMWWML (Ardini et al., 1998) were used for the combinations.

The combination peptides within our design are comprised of four types of results: the Tau ${ }^{\text {pep }}$ tandem sequence $\left(T_{a u}{ }^{\text {pep }}+T_{a u}{ }^{\text {pep }}\right)$, the sequence composed of $\mathrm{Tau}^{\text {pep }}$ linked to an NLS C-terminus (NLS + Tau ${ }^{\text {pep }}$ ), the sequence composed of Tau ${ }^{\text {pep }}$ linked to an LR Nterminus $\left(T a u^{\text {pep }}+L R\right)$, and the sequence composed of $\mathrm{Tau}^{\mathrm{pep}}+\mathrm{LR}$ linked to an NLS C-terminus (NLS+ $T a u^{\text {pep }}+L R$ ).

\section{Antibacterial activity of the $\mathrm{Tau}^{\text {pep }}$ tandem se- quence $\left(\mathrm{Tau}^{\mathrm{pep}}+\mathrm{Tau}^{\mathrm{pep}}\right.$ )}

The antibacterial function of $\mathrm{Tau}^{\mathrm{pep}}+\mathrm{Tau}^{\mathrm{pep}}$ peptides against S. aureus IFO12732 and E. coli IFO3972 was tested using the micro-dilution method with NB to evaluate their MICs. The Tau ${ }^{\text {pep }}$ simple sequences did not demonstrate antibacterial activity against $S$. aureus and E. coli. (MICs of $>50 \mu \mathrm{M}$ ). However, strong antibacterial activity was found when Taupep was made into a tandem sequence ( $\mathrm{Tau}^{\mathrm{pep}}+\mathrm{Tau}^{\mathrm{pep}}$ ). The results are shown in Table 2. MICs for three kinds of the $\mathrm{Tau}^{\mathrm{pep}}+\mathrm{Tau}^{\mathrm{pep}}$ peptides tested in NB were in the region of $1.6 \mu \mathrm{M}$ to $25 \mu \mathrm{M}$ against $S$. aureus and in the region of $6.3 \mu \mathrm{M}$ to $50 \mu \mathrm{M}$ against $E$. coli.

\section{Antibacterial activity of the sequence composed of $\mathrm{Tau}^{\text {pep }}$ linked to an NLS C-terminus (NLS+ $\mathrm{Tau}^{\mathrm{pep}}$ )}

$\mathrm{Tau}^{\text {pep }}$ was made into a combination sequence with NLS (NLS + Tau ${ }^{\text {pep }}$ ), and its MICs in NB were evaluated. The MIC results for seven kinds of peptides are
TABLE 2. MICs in nutrient broth for tandem sequences of Tau pep.

\begin{tabular}{rcc}
\hline \multirow{2}{*}{ Peptide } & \multicolumn{2}{c}{ MIC $(\mu \mathrm{M})$ in NB } \\
\cline { 2 - 3 } & $\begin{array}{c}\text { S. aureus } \\
\text { IFO12732 }\end{array}$ & $\begin{array}{c}\text { E. coli } \\
\text { IFO3972 }\end{array}$ \\
\hline Tau $^{\text {pep }}{ }_{1}+$ Tau $^{\text {pep }}{ }_{1}$ & 25 & 50 \\
Tau $^{\text {pep }}{ }_{5}+\operatorname{Tau}^{\text {pep }}{ }_{5}$ & 1.6 & 6.3 \\
$\operatorname{Tau}^{\text {pep }}{ }_{6}+\operatorname{Tau}^{\text {pep }}{ }_{6}$ & 6.3 & 50 \\
\hline
\end{tabular}

${ }^{a}$ Nutrient broth (NB) was the medium used.

TABLE 3. MICs in nutrient broth for combination peptides of $T a u^{\text {pep }}$ and NLS.

\begin{tabular}{|c|c|c|}
\hline \multirow[b]{2}{*}{ Peptide $^{a}$} & \multicolumn{2}{|c|}{$\mathrm{MIC}(\mu \mathrm{M})$ in $N \mathrm{~B}^{b}$} \\
\hline & $\begin{array}{l}\text { S. aureus } \\
\text { IFO12732 }\end{array}$ & $\begin{array}{c}\text { E. coli } \\
\text { IFO3972 }\end{array}$ \\
\hline $\mathrm{NLS}_{1}+\mathrm{Tau}^{\mathrm{pep}}$ & 3.1 & 6.3 \\
\hline $\mathrm{NLS}_{1}+\mathrm{Tau}^{\mathrm{pep}}{ }_{2}$ & 6.3 & $>50$ \\
\hline $\mathrm{NLS}_{1}+\mathrm{Tau}^{\mathrm{pep}{ }_{3}}$ & 3.1 & 12.5 \\
\hline $\mathrm{NLS}_{3}+\mathrm{Tau}^{\mathrm{pep}}{ }_{4}$ & 3.1 & 6.3 \\
\hline $\mathrm{NLS}_{3}+\mathrm{Tau}^{\mathrm{pep}{ }_{5}}$ & 0.8 & 3.1 \\
\hline $\mathrm{NLS}_{3}+\mathrm{Tau}^{\mathrm{pep}}{ }_{6}$ & 3.1 & 12.5 \\
\hline $\mathrm{NLS}_{2}+\mathrm{Tau}^{\mathrm{pep}} \mathrm{p}_{5}$ & 0.8 & 3.1 \\
\hline
\end{tabular}

${ }^{a} \mathrm{NLS}_{1}$ (Pax-QNR): LKRKLQR, NLS (NS5A): PPRKKRTVV, $\mathrm{NLS}_{3}$ (The analog sequence of SV40 Large $T$ antigen [PKKKRKV]): RKKKRKV.

${ }^{\circ}$ Nutrient broth (NB) was the medium used.

shown in Table 3. Strong antibacterial activity was found in the NLS+Taupep combinations, and their MICs were remarkably lower compared to the MICs for the $\mathrm{Tau}^{\text {pep }}+\mathrm{Tau}^{\text {pep }}$ tandem sequences. In $\mathrm{Tau}^{\mathrm{pep}}{ }_{1}$, $\mathrm{Tau}^{\mathrm{pep}}{ }_{5}$, and $\mathrm{Tau}^{\mathrm{pep}}{ }_{6}$, antibacterial performance for the combination with NLS were from two to four times that of the tandems on their own. Their MICs against $S$. aureus and E. coli were $\leq 3.1 \mu \mathrm{M}$ and $\leq 12.5 \mu \mathrm{M}$ respectively.

To further evaluate the antibacterial function of the $\mathrm{NLS}+\mathrm{Tau}^{\text {pep }}$ combination sequences, $\mathrm{MHB}$ including $\mathrm{CaCl}_{2}$ and $\mathrm{MgCl}_{2}$ (ca. MHB) was used as the medium 
TABLE 4. MICs in cation-adjusted Mueller-Hinton broth for combination peptides of $\mathrm{Tau}^{\mathrm{pep}}$ and NLS.

\begin{tabular}{|c|c|c|}
\hline \multirow[b]{2}{*}{ Peptide ${ }^{a}$} & \multicolumn{2}{|c|}{$\mathrm{MIC}(\mu \mathrm{M})$ in ca. $\mathrm{MHB}^{b}$} \\
\hline & $\begin{array}{l}\text { S. aureus } \\
\text { IFO12732 }\end{array}$ & $\begin{array}{c}\text { E. coli } \\
\text { IFO3972 }\end{array}$ \\
\hline $\mathrm{NLS}_{1}+\mathrm{Tau}^{\mathrm{pep}}$ & 25 & $>50$ \\
\hline $\mathrm{NLS}_{1}+\mathrm{Tau}_{2}^{\mathrm{pep}}$ & $>50$ & $>50$ \\
\hline $\mathrm{NLS}_{1}+\mathrm{Tau}^{\mathrm{pep}}{ }_{3}$ & 25 & $>50$ \\
\hline $\mathrm{NLS}_{3}+\mathrm{Tau}^{\mathrm{pep}}{ }_{4}$ & 25 & $>50$ \\
\hline $\mathrm{NLS}_{3}+\mathrm{Tau}_{5}^{\mathrm{pep}_{5}}$ & 3.1 & $>50$ \\
\hline $\mathrm{NLS}_{3}+\mathrm{Tau}_{6}^{\mathrm{pep}}$ & 25 & $>50$ \\
\hline $\mathrm{NLS}_{3}+\mathrm{Tau}_{7}^{\mathrm{pep}}$ & 6.3 & $>50$ \\
\hline $\mathrm{NLS}_{3}+\mathrm{Tau}_{8}^{\mathrm{pep}}$ & 12.5 & 25 \\
\hline $\mathrm{NLS}_{2}+\mathrm{Tau}_{5}^{\mathrm{pep}_{5}}$ & 6.3 & $>50$ \\
\hline $\mathrm{NLS}_{2}+\mathrm{Tau}_{6}^{\mathrm{pep}}$ & 50 & $>50$ \\
\hline
\end{tabular}

${ }^{a} \mathrm{NLS}_{1}$ (Pax-QNR): LKRKLQR, NLS 2 (NS5A): PPRKKRTVV, $\mathrm{NLS}_{3}$ (The analog sequence of SV40 Large $\mathrm{T}$ antigen [PKKKRKV]): RKKKRKV.

${ }^{b}$ Cation-adjusted Mueller-Hinton broth (ca. MHB) was the medium used.

for the antibacterial assay. By using this medium, it was possible to test if the peptides were affected by cations such as calcium or magnesium. In addition, any effects from salt could also be tested because MHB already includes $\mathrm{NaCl}$, unlike NB. The results are shown in Table 4. In ca. MHB, most peptides lost antibacterial activity against $E$. coli, but retained high activity against $S$. aureus. The MICs of the peptides without $\mathrm{NLS}_{1}+\mathrm{Tau}^{\mathrm{pep}}{ }_{2}$ were in the region of $3.1 \mu \mathrm{M}$ to $50 \mu \mathrm{M}$.

$\mathrm{NLS}_{1}+\mathrm{Tau}^{\text {pep }}{ }_{3}, \mathrm{NLS}_{3}+\mathrm{Tau}^{\text {pep }}{ }_{5}, \mathrm{NLS}_{3}+\mathrm{Tau}^{\text {pep }}{ }_{6}$, and $\mathrm{NLS}_{2}+\mathrm{Tau}^{\mathrm{pep}}{ }_{5}$, which demonstrated high antibacterial activity in $\mathrm{NB}$ and $\mathrm{ca}$. MHB, were further tested using $\mathrm{MHB}$ and ca. sera. MHB (cation-adjusted MHB prepared with $10 \%$ horse serum) and the results are shown in Table 5. Antibacterial activity for these peptides against $E$. coli decreased in MHB more than four times compared with the activity in NB, and no activ- ity was found in ca. MHB or ca. sera. MHB. However, antibacterial activity for these peptides against $S$. aureus was found in all of the mediums. Although the activity became slightly weaker whenever the elements salt, cations, or serum were added into the medium, the effect of the elements was not strong. In fact, $\mathrm{NLS}_{3}+\mathrm{Tau}^{\mathrm{pep}}{ }_{5}$ demonstrated remarkable antibacterial activity against $S$. aureus (MICs of $3.1 \mu \mathrm{M}$ ) in $\mathrm{MHB}$, ca. $\mathrm{MHB}$, and ca. sera. $\mathrm{MHB}$ while having a $\mathrm{MIC}$ of $0.8 \mu \mathrm{M}$ in NB. NLS${ }_{2}+\mathrm{Tau}^{\mathrm{pep}}{ }_{5}$ also demonstrated high activity even in serum (MIC of $25 \mu \mathrm{M}$ ).

Consequently, it was demonstrated that $\mathrm{Tau}^{\mathrm{pep}}$ obtains significant antibacterial activity against $S$. aureus and its activity is not strongly affected by $\mathrm{NaCl}, \mathrm{CaCl}_{2}, \mathrm{MgCl}_{2}$, or even horse serum when $\mathrm{Tau}^{\text {pep }}$ was made into a combination sequence with various kinds of NLS.

\section{Antibacterial activity of the sequence composed of Tau ${ }^{\text {pep }}$ linked to an LR $\mathrm{N}$-terminus ( $\mathrm{Tau}^{\mathrm{pep}}+\mathrm{LR}$ ), and the sequence composed of Tau pep + LR linked to an NLS C-terminus (NLS+Tau ${ }^{\text {pep }}+\mathrm{LR}$ )}

In addition to combination sequences consisting of the same peptides ( $\left.\mathrm{Tau}^{\mathrm{pep}}+\mathrm{Tau}^{\mathrm{pep}}\right)$, experiments were performed to determine the antibacterial function of the combination sequences between different kinds of peptides derived from other proteins. Taupep $+L R$, a combination between a sequence derived from the binding site on a tau protein and a sequence derived from a binding site of another protein (LR) was tested. $L R$ is a peptide derived from the binding site of a laminin receptor, which mediates strong attachment of cells to laminin and its potential to be a useful component for antimicrobial peptides has been reported previously (Kobayashi and Yoshida, 2007). The results of the examination are shown in Table 6. The antibacterial activity of $\mathrm{Tau}^{\mathrm{pep}}{ }_{5}+\mathrm{LR}$ was quite strong against $S$. aureus and almost the same as that of $\mathrm{Tau}^{\text {pep }}{ }_{5}+\mathrm{Tau}^{\text {pep }}{ }_{5}$ and $\mathrm{NLS}_{2}+\mathrm{Tau}^{\mathrm{pep}}{ }_{5}$, but was still

TABLE 5. Comparison of MICs in various mediums for combination peptides of Tau ${ }^{\text {pep }}$ and NLS.

\begin{tabular}{|c|c|c|c|c|c|c|c|c|}
\hline \multirow{3}{*}{ Peptide $^{a}$} & \multicolumn{8}{|c|}{$\operatorname{MIC}(\mu \mathrm{M})^{b}$} \\
\hline & \multicolumn{4}{|c|}{ S. aureus IFO12732 } & \multicolumn{4}{|c|}{ E. coli IFO3972 } \\
\hline & NB & $\mathrm{MHB}$ & ca.MHB & $\begin{array}{c}\text { ca.sera. } \\
\text { MHB }\end{array}$ & NB & $\mathrm{MHB}$ & ca.MHB & $\begin{array}{c}\text { ca.sera. } \\
\text { MHB }\end{array}$ \\
\hline $\mathrm{NLS}_{1}+\mathrm{Tau}^{\mathrm{pep}}{ }_{3}$ & 3.1 & 12.5 & 25 & $>50$ & 12.5 & 50 & $>50$ & $>50$ \\
\hline $\mathrm{NLS}_{3}+\mathrm{Tau}^{\mathrm{pep}}{ }_{5}$ & 0.8 & 3.1 & 3.1 & 3.1 & 3.1 & 50 & $>50$ & $>50$ \\
\hline $\mathrm{NLS}_{3}+\mathrm{Tau}_{6}^{\mathrm{pep}}$ & 3.1 & 6.3 & 25 & $>50$ & 12.5 & $>50$ & $>50$ & $>50$ \\
\hline $\mathrm{NLS}_{2}+\mathrm{Tau}^{\mathrm{pep}}$ & 0.8 & 3.1 & 6.3 & 25 & 3.1 & 12.5 & $>50$ & $>50$ \\
\hline
\end{tabular}

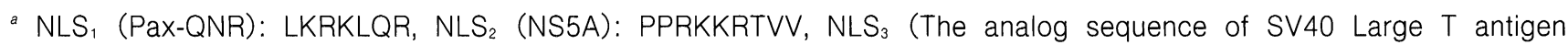
[PKKKRKV]): RKKKRKV.

${ }^{b}$ Nutrient broth (NB), Mueller-Hinton broth (MHB), cation-adjusted MHB (ca. MHB), and cation-adjusted MHB with $10 \%$ horse serum (ca. sera. MHB) were the mediums used. 
TABLE 6. Comparison of MICs in various mediums for combination peptides of Tau ${ }^{\text {pep }}$, NLS and Laminin Receptor peptide (LR).

\begin{tabular}{|c|c|c|c|c|c|c|c|c|}
\hline \multirow{3}{*}{ Peptide $^{a}$} & \multicolumn{8}{|c|}{$\operatorname{MIC}(\mu \mathrm{M})^{b}$} \\
\hline & \multicolumn{4}{|c|}{ S. aureus IFO12732 } & \multicolumn{4}{|c|}{ E. coli IFO3972 } \\
\hline & NB & $\mathrm{MHB}$ & ca.MHB & $\begin{array}{c}\text { ca.sera. } \\
\text { MHB }\end{array}$ & NB & $\mathrm{MHB}$ & ca.MHB & $\begin{array}{c}\text { ca.sera. } \\
\text { MHB }\end{array}$ \\
\hline $\mathrm{Tau}^{\mathrm{pep}}{ }_{5}+\mathrm{LR}$ & 3.1 & 3.1 & 6.3 & 12.5 & 12.5 & 25 & $>50$ & $>50$ \\
\hline $\mathrm{NLS}_{3}+\mathrm{Tau}^{\mathrm{pep}}{ }_{5}+\mathrm{LR}$ & 3.1 & 3.1 & 6.3 & 3.1 & 3.1 & 6.3 & 6.3 & 25 \\
\hline $\mathrm{NLS}_{3}+\mathrm{Tau}^{\mathrm{pep}}{ }_{5}$ & 0.8 & 3.1 & 3.1 & 3.1 & 3.1 & 50 & $>50$ & $>50$ \\
\hline
\end{tabular}

${ }^{a} \mathrm{NLS}_{3}$ (The analog sequence of SV40 Large T antigen [PKKKRKV]): RKKKRKV. LR (Laminin-binding site on human laminin receptor): LMWWML.

${ }^{b}$ Nutrient broth (NB), Mueller-Hinton broth (MHB), cation-adjusted MHB (ca. MHB), and cation-adjusted MHB with $10 \%$ horse serum (ca. sera. MHB) were the mediums used.

TABLE 7. MICs for combination peptides of Tau ${ }^{\text {pep }}$, NLS and Laminin Receptor peptide (LR) for fungus.

\begin{tabular}{lcc}
\hline \multirow{2}{*}{ Peptide $^{a}$} & \multicolumn{2}{c}{$\mathrm{MIC}(\mu \mathrm{M})^{b}$} \\
\cline { 2 - 3 } & C. albicans & C. albicans \\
& NBRC1594 & TIMM3165 \\
\hline $\mathrm{Tau}^{\text {pep }}+\mathrm{LR}$ & 70 & $>70$ \\
$\mathrm{NLS}_{3}+\mathrm{Tau}^{\text {pep }}{ }_{5}+\mathrm{LR}$ & 5.8 & 5.8 \\
$\mathrm{NLS}_{3}+\mathrm{Tau}_{5}^{\text {pep }}$ & 8.5 & 8.5 \\
\hline
\end{tabular}

${ }^{*} \mathrm{NLS}_{3}$ (The analog sequence of SV40 Large $\mathrm{T}$ antigen [PKKKRKV]): RKKKRKV. LR (Laminin-binding site on human laminin receptor): LMWWML.

${ }^{b}$ RPMI 1640 broth was the medium used.

weak against E. coli. However, by introducing NLS into the combination with the $T a u^{\text {pep }}{ }_{5}+L R$, the antibacterial activity surprisingly improved against $E$. coli. The MICs of $\mathrm{NLS}_{3}+\mathrm{Tau}^{\text {pep }}{ }_{5}+\mathrm{LR}$ against $E$. coli were $3.1 \mu \mathrm{M}, 6.3 \mu \mathrm{M}, 6.3 \mu \mathrm{M}$, and $25 \mu \mathrm{M}$ in $\mathrm{NB}, \mathrm{MHB}$, ca. $\mathrm{MHB}$, and ca. sera. MHB, respectively. Of course, the activity against $S$. aureus remained strong with MICs of $\leq 6.3 \mu \mathrm{M}$ in the all of the mediums. Thus, combinations based on the binding sites derived from different proteins were useful for designing antimicrobial peptides.

\section{Antifungal activity of the NLS $+\mathrm{Tau}^{\text {pep }}, \mathrm{Tau}^{\mathrm{pep}}+\mathrm{LR}$, and NLS+Tau ${ }^{\text {pep }}+$ LR}

Experiments were also done to determine whether an antifungal potential would be found in the combination sequences between different kinds of peptides derived from other proteins. MICs of the $\mathrm{NLS}_{3}+$ $\mathrm{Tau}_{5}^{\mathrm{pep}} \mathrm{Tau}_{5} \mathrm{Tep}_{5}+\mathrm{LR}$, and $\mathrm{NLS}_{3}+\mathrm{Tau}^{\mathrm{pep}}{ }_{5}+\mathrm{LR}$ against $C$. albicans strains were evaluated and the results are shown in Table 7. The $\mathrm{NLS}_{3}+\mathrm{Tau}^{\text {pep }}{ }_{5}$ and $\mathrm{NLS}_{3}+$ $\mathrm{Tau}^{\mathrm{pep}}+\mathrm{LR}$ showed strong antifungal activity and their MICs were $8.5 \mu \mathrm{M}$ and $5.8 \mu \mathrm{M}$ respectively. The Tau ${ }^{\text {pep }}{ }_{5}+$ LR did not have antifungal activity $(\geq 70$ $\mu \mathrm{M}$ ). The results suggested that combinations have antifungal potential although it depends on the combination as with the antibacterial potential.

\section{DISCUSSION}

Examining the results, it was discovered that an antimicrobial function is inherent in the peptides based on the binding sites of tau proteins and the function does not disappear even with the existence of salt, $\mathrm{MgCl}_{2}, \mathrm{CaCl}_{2}$, or horse serum. Tau ${ }^{\text {pep }}+\mathrm{Tau}^{\text {pep }}$, NLS + Tau ${ }^{\text {pep }}$, and Tau pep + LR demonstrated a particularly strong effect against $S$. aureus which is a grampositive bacterium. In addition, NLS + Tau pep $+L R$ demonstrated a strong effect against both $S$. aureus and $E$. coli, which is a gram-negative bacterium. Moreover NLS + Tau ${ }^{\text {pep }}$ and NLS + Tau ${ }^{\text {pep }}+$ LR demonstrated antifungal activity against $C$. albicans. An arrangement such as this could produce better antimicrobial function in tau-derived peptides. The outer membrane of gram-negative bacteria is negatively charged and more hydrophilic than the membrane of gram-positive bacteria, so the NLS + Tau ${ }^{\text {pep }}$ +LR peptide could obtain a strong interaction with the membrane of $E$. coli by combining it to the positively charged NLS. However, if too many positive charges exist in a peptide sequence, the peptide easily gets affected by salt, cations, and serum which are all elements included in blood and it loses a wide spectrum of antimicrobial function. When designing antibacterial peptides, it is necessary to consider the balance of positive charges and negative charges in addition to the individual function of the materials. From this point of view, various kinds of cation balances for antimicrobial peptides could be produced by combinating $\mathrm{Tau}^{\mathrm{pep}}$ and peptides derived from other proteins and signal peptides such as NLS. This way, the antimicrobial peptides would have the capability to maintain antimicrobial activity against various microbes. 
A new design principle that focuses on the functional regions of a variety of proteins which do not exist solely for self-defense in nature can be established for peptide antibiotics. In designing antibiotics, it is important to consider how the antibiotic interacts with the microbial membrane. Binding domains of proteins are often structurally stable and composed of amphipathic helices, so it would be worth focusing on these binding domains in particular as components for antimicrobial peptides which can effectively interact with microbial membranes.

Our design concept for antimicrobial peptides takes the design principle of focusing on protein functional regions and adds the idea of "combination" to it. Because a large number of combinations can be produced by combining peptides based on the functional regions, it is possible to quickly screen much more effective peptide antibiotics against new resistant microbes. When components of $\mathrm{A}$ and $\mathrm{B}$ are used in design, the antimicrobial activities of the $A+B$ sequences are almost identical to that of the $B+A$ sequences. In combination peptides, the antimicrobial effect does not change even if the order of components is changed, but the ways they interact with microbes might be subtly different. This suggests that the $B+A$ sequences might be effective against microbes which have grown resistant to the $A+B$ sequences. Another benefit of this idea is that the cation balances, which are important for antimicrobial peptides when interacting with negatively charged microbial membranes, could be controlled by combining different peptides. Each microbe has a different quantity of net charge on the membrane. For example, the membranes of gram-negative bacteria are more hydrophilic than the membranes of gram-positive bacteria and are strongly reinforced by cations in a simulated environment of blood. Considering a peptide cation balance suitable for each microbial membrane is necessary to facilitate the microbe-specific interaction of antimicrobial peptides.

Our experiments demonstrate that Tau peptides possess high potential for becoming components in antimicrobial peptides. Moreover, this finding reinforces our hypothesis that combination designs based on binding sites of proteins could become a useful method in peptide antibiotic research.

\section{ACKNOWLEDGEMENT}

We thank the Teikyo University Institute of Medical Mycology (TIMM) for providing C. albicans TIMM3165.

\section{REFERENCES}

Ardini, E., Pesole, G., Tagliabue, E., Magnifico, A., Castronovo, V., Sobel, M. E., Colnaghi, M. I., and Menard, $\mathrm{S}$. (1998) The $67-\mathrm{kDa}$ laminin receptor originated from a ribosomal protein that acquired a dual function during evolution. Mol. Biol. Evol., 15, 1017-1025.

Bergen, V. M., Friedhoff, P., Biernat, J., Heberle, J., Mandelkow, E.-M., and Mandelkow, E. (2000) Assembly of $\tau$ protein into Alzheimer paired helical filaments depends on a local sequence motif ( ${ }^{306} \mathrm{VQIVYK}{ }^{311}$ ) forming $\beta$ structure. Proc. Natl. Acad. Sci. USA, 97, 5129-5134.

Casteels, P., Ampe, C., Jacobs, F., Vaeck, M., and Tempst, P. (1989) Apidaecins: antibacterial peptides from honeybees. EMBO J., 8, 2387-2391.

Cleveland, D. W., Hwo, S. Y., and Kirschner, M. W. (1977) Purification of tau, a microtubule-associated protein that induces assembly of microtubules from purified tubulin. J. Mol. Biol., 116, 207-25.

Drechsel, D. N., Hyman, A. A., Cobb, M. H., and Kischner, M. W. (1992) Modulation of the dynamic instability of tubulin assembly by the microtubule-associated protein tau. Mol. Biol. Cell, 3, 1141-1154.

Goedert, M., and Jakes, R. (1990) Expression of separate isoforms of human tau protein: correlation with the tau pattern in brain and effects on tubulin polymerization. EMBO J., 9, 4225-4230.

Goode, B. L., and Feinstein, S. C., (1994) Identification of a novel microtubule binding and assembly domain in the developmentally regulated inter-repeat region of tau. $J$. Cell Biol., 124, 769-782.

Goode, B. L., Denis, P. E., Panda, D., Radeke, M. J., Miller, P. H., Wilson, L., and Feinstein, C. S. (1997) Functional interactions between the proline-rich and repeat regions of tau enhance microtubule binding and assembly. Mol. Biol. Cell, 8, 353-365.

Goode, B. L., Chau, M., Denis, P. E., and Feinstein, S. C. (2000) Structural and functional differences between 3repeat and 4-repeat tau isoforms. J. Biol. Chem., 275, 38182-18289.

Kobayashi, N., Yamada, Y., and Yoshida, T. (2006a) Nuclear translocation peptides as antibiotics. Antimicrob. Agent Chemother., 50, 1118-1119.

Kobayashi, N., Sato, T., and Yoshida, T. (2006b) Antiviral properties of combination peptides of HIV-1 Rev NLS and NES. Protein Pept. Lett., 13, 1025-1027.

Kobayashi, N., and Yoshida, T. (2006) Antimicrobial properties of nuclear diffusion inhibitory signal of HIV-1 Rev. Protein Pept. Lett., 13, 805-806.

Kobayashi, N., and Yoshida, T. (2007) Binding sites on laminin receptors as components for antibiotics. Protein Pept. Lett., 14, 33-36.

Lee, V. M.-Y., Goedert, M., and Trojanowski, J. Q. (2001) Neurodegenerative tauopathies. Annu. Rev. Neurosci., 24, 1121-1159.

Mygind, P. H., Fischer, R. L., Schnorr, K. M., Hansen, M. T., Sonksen, C. P., Ludvigsen, S., Raventos, D., Buskov, S., Christensen, B., De Maria, L., Taboureau, O., Yaver, D., Elvig-Jorgensen, S. G., Sorensen, M. V., Christensen, B. E., Kjaerulff, S., Frimodt-Moller, N., Lehrer, R. I., Zasloff, M., and Kristensen, H. H. (2005) Plectasin is a peptide antibiotic with therapeutic potential from a saprophytic fungus. Nature, 437, 975-980.

Selsted, M. E., Harwig, S. S., Ganz, T., Schilling, J.W., and Lehrer, R. I. (1985) Primary structure of three human 
neutrophil defensins. J. Clin. Invest., 76, 1436-1439.

Silphaduang, U., and Noga, E. J. (2001) Peptide antibiotics in mast cells of fish. Nature, $\mathbf{4 1 4}, 268-269$.

Steiner, H., Hultmark, D., Engstrom, A., Bennich, H., and Boman, H. G. (1981) Sequence and specificity of two antibacterial proteins involved in insect immunity. Nature, 292, 246-268.
Zasloff, M. (1987) Magainins, a class of antimicrobial peptides from Xenopus skin: isolation, characterization of two active forms, and partial cDNA sequence of a precursor. Proc. Natl. Acad. Sci. USA, 84, 5449-5453.

Zasloff, M. (2002) Antimicrobial peptides of multicellular organisms. Nature, 415, 389-395. 